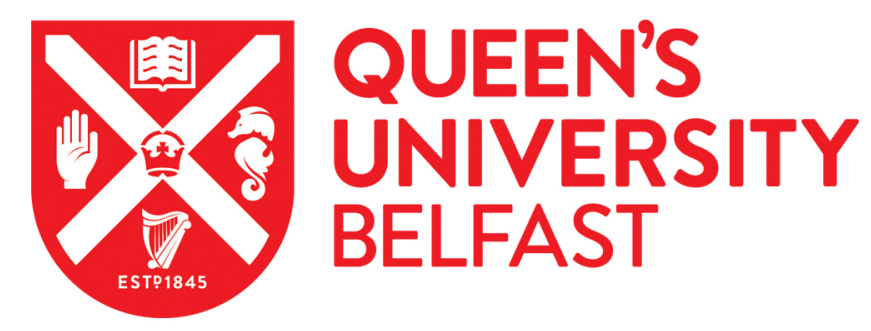

\title{
The birth of neoprofessionalism in the context of neoliberal governmentality: The case of productive university teachers
}

Chiang, T-H., Thurston, A., \& Lee, J. C. K. (2020). The birth of neoprofessionalism in the context of neoliberal governmentality: The case of productive university teachers. International Journal of Educational Research, 121. https://doi.org/10.1016/j.ijer.2020.101582

Published in:

International Journal of Educational Research

Document Version:

Peer reviewed version

Queen's University Belfast - Research Portal:

Link to publication record in Queen's University Belfast Research Portal

Publisher rights

Copyright 2020 Elsevier.

This manuscript is distributed under a Creative Commons Attribution-NonCommercial-NoDerivs License

(https://creativecommons.org/licenses/by-nc-nd/4.0/), which permits distribution and reproduction for non-commercial purposes, provided the author and source are cited.

\section{General rights}

Copyright for the publications made accessible via the Queen's University Belfast Research Portal is retained by the author(s) and / or other copyright owners and it is a condition of accessing these publications that users recognise and abide by the legal requirements associated with these rights.

Take down policy

The Research Portal is Queen's institutional repository that provides access to Queen's research output. Every effort has been made to ensure that content in the Research Portal does not infringe any person's rights, or applicable UK laws. If you discover content in the Research Portal that you believe breaches copyright or violates any law, please contact openaccess@qub.ac.uk. 


\title{
The birth of neoprofessionalism in the context of neoliberal governmentality:
} The case of productive university teachers

\author{
Distinguished Professor Tien-Hui Chiang \\ Academy of Globalization and Education Policy, Zhengzhou University, China \\ thchiang@zzu.edu.cn \\ Professor Allen Thurston \\ Queen's University Belfast, UK \\ a.thurston@qub.ac.uk \\ Vice President John Chi Kin Lee \\ The Education University of Hong Kong, Hong Kong \\ jcklee@eduhk.hk
}

\begin{abstract}
For M. Foucault, governmentality takes population as its subject and object in order to transform the targeted people into enterprising subjects by reconstituting their subjectivities, so that the art of government is to instill rules of conduct into their self-knowledge via their souls. In the regime of neoliberal governmentality, international competitiveness comes to define teachers as the source of a problem undermining national prospects. In order to improve the quality of human capital, the strategy of performance management is introduced. Foucauldian scholars conceptualize its negative influence on teachers as performativity, illustrating how they are subject to social returns. While performativity is able to foreground the dark side of performance management policy, Foucauldian researchers may overlook its positive influence on productive faculty members. In order to examine this possible aspect, 16 individual interviews were completed in sampled regions. The findings show that although productive university teachers suffered a considerable amount of pressure from this policy, it facilitated them to validate their academic commitment and to acquire social status. This validation subscribed the culture of neoprofessionalism.
\end{abstract}

Keywords: neoliberal governmentality, the discourse of international competitiveness, performance management, performativity, neoprofessionalism

\section{Introduction}

Neoliberalism won an unprecedented victory in the political sphere when American presidents, starting from R. Reagan in 1981, adopted free market logic to undertake political and economic reforms (Harvey, 2005). It has further attained hegemonic status in the world through the dissemination of international financial institutes (Chiang, 2011), such as the OECD (Rizvi and Lingard, 2006), the IMF, the 
WB (Hytrek and Zentgraf, 2008; Stiglitz, 2006) and the WTO (Robertson, Bonal and Dale, 2006), which are largely under the control of America. As neoliberalists believe that a free market is able to improve efficiency and ensure service quality, principles of entrepreneurialism are applied to the public sector. This approach has created public managerialism (Chiang, 2014, 2016; Currie, 2004; Heywood, 2003, Lingard, 2000), which has been widely adopted by many countries incarnated in Site-based Management in the USA, Self Managing Schools in Australia (Blackmore, 2006) and Self Government Schools in New Zealand (Codd, Gordon and Harker, 1997). While related studies report that this efficiency-led approach is likely to push higher education institutes into becoming knowledge factories subject to market demands (Bok, 2003) or a national enterprise complying with the rules of instrumental rationality (Blackmore, 2006), Foucauldian researchers further invoke the concept of biopolitics, proposed by Foucault (2010), to examine the influence of neoliberal governmentality on teachers. It is argued that performance management policy carries out the art of governance because it is able to proliferate teachers' commitment to excellent performance through association with social recognition (Ball, 2006). The discourse of international competitiveness further reinforces the necessity of this policy because this discourse aligns human capital with education results and this alignment compels teachers to contribute to national economic development (Robertson, 2012). Unfortunately, teachers have been accused of failing in this national assignment, so that teacher-asproblem has become a global grammar initiating education reforms (Thompson and Cook, 2014), locking teachers into the cage of performativity and delivering a moral system transforming them into enterprising subjects (Ball and Olmedo, 2013) motivated to acquire social returns by enhancing their productivity (Ball, 2003). However, the power deployment of neoliberal governmentality cannot eliminate the self-reflection of teachers, as evident in policy enactment (Maguire, Braun and Ball, 2015) or in resistance to or even refusal to cooperate with nonimperative education policies (Ball and Olmedo, 2013; Maguire, Braun and Ball, 2018). Such self-awareness makes the recovery of their subjectivities become possible (Ball, 2016). While the above findings foreground the dark side of performativity, the positive influence of performance management policy on productive university teachers remains unknown. Hence, this study sets out to explore how productive teachers may perceive, evaluate and react to this policy, and why.

\section{Governmentality}

Foucault (1991: 135-169) argues that schooling is able to hatch docile bodies who strongly support the existing social structure. This connection projects the axiom that disciplined subjects make great contributions to the development of social 
normalization. Although normalization deprives people's minds of their critical faculty, social operation can be stably sustained. This power array can be observed in the history of sexuality, in which medical knowledge came to convert people's sexual impulses into a civilized form that proliferated their commitment to the mode of capitalist production (Foucault, 1990: 3-13, 103-131). In his late work, Foucault (2010) elaborates on this power deployment by pointing out that the self plays as the core element in constituting biopolitics, which takes population as its subject and object. This phenomenon reflects why governance becomes reflexive (raison d'État) shifting the means of social control from the juridical system to market freedom, which encourages consumers to use rational behaviours. The advantages of a free market, including social justice veridiction, rational judgement and democratic function, urge the practice of sovereignty to shift from government to reflexive government, conceptualized as governmentality (Foucault, 2010: 8-37). Accordingly, in order to secure social security, what the government needs to do is to promote the status of market freedom, which is able to maximize people's rationalized minds leading to the generation of automatically self-regulated acts. Nevertheless, the free market no longer operates in the laissez-faire form of the eighteenth century, but in a neoliberal mode, addressing competition to form enterprising subjects (Foucault, 2010: 116-133, 295320). This was the core component of the ordoliberalism employed by the German government in the 1930s (Foucault, 2010: 80-94, 146-150). When competition is the core element of market freedom, the art of governing technologies is not to instruct social members but to administrate their lifestyle (Foucault, 2010: 80-94). Its purpose is to teach people how to think and how to act (Popkewitz, 1994).

In this sense, self is the nexus between power and self-regulation. Foucault further points out that self is the subjectivity associated with self-knowledge or selfconsciousness, which initiates thought and behaviour. Therefore, in order to gear people's behaviours, the art of governance is to install care of the self into their selfknowledge. Regarding this social alchemy, there is a long historical evolution, originally presented in the form of 'concern yourself' (epimeleia heautou) and later transforming itself into 'know yourself' (gnōthi seauton). Philosophical and religious factors later infused more subtle meanings into 'know yourself' as evident in 'attending to yourself' proposed by Socrates (Foucault, 2005: 1-9), 'looking at yourself' argued by Plato (Foucault, 2005: 68-69), and the asceticism of Christianity (Foucault, 2005: 9-19). These historical movements semantically turn 'concern yourself' (epimeleia heautou) into care of self and interlink care of self with 'know yourself' (gnōthi seauton). Accordingly, two interlocking principles emerge, namely care of self, which exists in knowledge of self, and knowledge of self, which energizes care of self. As care of self is about knowing yourself, recollection, gaze or mediation functions as the source of 
knowledge and thought, so that souls are the infrastructure of developing selfknowledge (Foucault, 2005: 65-79, 254-263). As souls serve as the gateway for channeling ideas, thoughts and values to people's self-consciousness, governing souls becomes the most powerful governing technology in modern society (Ross, 1999).

Because social moralities pronounce the rules of authentic or at least decent conduct and manner, ethics serves as the toolkit for composing self-knowledge or performing care of self via souls. In this regard, civil society is the gateway for transmitting such governing techniques due to its consensual form securing the common good, as evident in the cases of the development of the French magistracy (Foucault, 2003: 115-140) and the evolution of the laws of the Saxon regime (Foucault, 2003: 87-114), both of which signify state sovereignty anchored by civil society, in which the state needs to be cognizant of the people's voice. Although ethics is able to enlighten people's self-knowledge in their souls via civil society, it needs to be accepted by them. In order to convince the public, ethics needs to be exerted in the form of truthtelling, a concept originally referring to free speech with frankness at any cost (Parrēsia)

(Foucault, 2011:36-66), but later accomplishing a technique of forming self-knowledge

(Foucault, 2011: 65-79, 199-206). In this case, truth-telling functions as a conduit for leading him or her to look at himself or herself, so that self-monitoring is constantly in operation. Furthermore, as people are used to employing their own knowledge to observe others, looking at each other leads truth-telling to possess the mechanism of collective surveillance (Foucault, 2011: 303-6). The combination of self-regulation and collective surveillance generates the mechanism of 'governing at a distance', which allows authorities to exercise their function in an invisible way, envisaged as 'governing without governing society' (Dean, 2010: 207-222), and is evident in various domains, such as childhood parental education (Gewirtz, 2008) and lifelong learning (Andersson, and Fejes, 2005; Säfström, 2005). In this sense, governmentality can be conceptualized as the process of governmentalization of governance, shifting from government to 'reflexive government', which is able to calculate social risk in governmental rationality for governing the conduct of individuals, collectives and populations. Its attempt is to reformulate targeted people into governable subjects subscribing to the ethics of self-improvement (Dean, 2010: 207-222) by inscribing 'rules of conduct' or 'conduct of conduct' into self-knowledge (Dean, 2010: 19, 117-132).

\section{Neoliberalism and performance management}

The discourse of international competitiveness, disseminated by international institutes, interlinks good quality teaching with human capital that secures national prospects. This discourse thus delivers collective responsibility from the government to 
teachers (Robertson, 2012; Thompson and Cook, 2014). Because teachers are alleged to have failed in this national mission, the state acquires legitimate authority to interfere with the teaching profession, by which teachers become the targeted population (Singh, 2015), so that teacher-as-problem functions as a global grammar provoking related education reforms (Thompson and Cook, 2014). As these international institutes appreciate the logic of entrepreneurialism, public managerialism becomes the philosophy driving these reforms. Public managerialism is mainly exercised through three tactics, devolution, empowerment and accountability (Codd, Gordon and Harker, 1997), and aims to transform teachers into responsible subjects who acknowledge their own identity and responsibility. Unlike Taylorism, public managerialism accommodates high trust through devolution in order to proceed with innovative actions. When teachers are empowered, they are expected to be responsible for education outcomes (Ball, 1998). These methods are consistent with the argument of Dean (2010, 223-258), depicting the relation between technologies of agency and technologies of performance, illustrating how empowerment proliferates professional identity that reconfigures teachers into enterprising subjects who can optimize their output through their commitment.

In this regard, public management commands teachers to demonstrate their ability measurably in students' learning outcomes. Competitions between and within the empowered units further align performance with social rewards and sanctions. This alignment creates the mechanism of performativity carrying out the device of mental classification, allocating teachers into poor or good groups according to their performance. Good groups acquire positive social symbols such as excellence, dignity, pride and honor. In contrast, their poorly performing counterparts are inevitably stigmatized with incapability, shame and guilt (Ball, 2006). This difference becomes the meter demarcating people's contributions to social development, so that performativity is able to create a moral system transforming teachers into governable subjects (Ball and Olmedo, 2013), who are motivated to win social recognition through their productivity (Ball, 2003). Truth-telling here dispatches teaching ethics prescribing the code of conduct. Excellent teachers behave as truth-tellers, presenting an example for others, and this situation ushers teachers to look at themselves and each other. The combination of self-monitoring and collective surveillance comes to shape the self of the self (Perryman, Ball, Braun and Maguire, 2017). The self of the self is activated by engagement that scatters ethical elements urging teachers to become the model for their colleagues. When the regime of truth is able to form the terrain of the will to know, teachers are refabricated into enterprising subjects underwriting performance management (Ball, 2016). In this scene, performativity is the rhetoric of belief and commitment, enabling the government to manipulate care of self, the principle that 
people dedicate themselves to constantly maximizing their outputs (Ball, 2003), as evident in the case of university senior administrators in Ireland, who legitimized performance management as an instrument, forcing their colleagues to prove their own abilities in publications or research grants (Morrissey, 2013). This is the art of self that performs in pastoral guidance and effective and inspirational leadership embedded within excellent demonstrations, the techniques of which come to reconstitute the self of the self (Olmedo, Bailey and Ball, 2013), which operates in the form of noninterventionary intervention due to the voluntarism of teachers' souls (Ball, 1998).

In the regime of neoliberal governmentality, subjectivities thus become the locus of power struggle (Ball and Olmedo, 2013). While teachers and education administrators may be reformatted into enterprising subjects complying with the imperatives of education policy, their subjectivities still remain to some extent, as evident in policy enactment, the processes of which consist of interpretation, negotiation and translation foregrounding their independent autonomy, allowing them to act not as policy implementers but as policy interpreters and translators. A variety of factors have forged this phenomenon, such as different personal experiences and commitments (Maguire, Braun and Ball, 2015), and the gap between performance management policy and local needs (Singh, Heimans and Glasswell, 2014; Singh, Pini and Glasswell, 2018; Singh, Thomas and Harris, 2013). Beside policy enactment, related studies further found that teachers resisted or even refused to implement regulations or policies that unreasonably increased their workloads (Maguire, Braun and Ball, 2018) or overestimated their abilities (Ball and Olmedo, 2013). As both refusal and resistance were related to care of the self, this circumstance stimulated selfreflections (Ball and Olmedo, 2013), enabling the teachers to retrieve their selfconsciousness and restore their independent subjectivities (Ball, 2016).

To sum up, neoliberal government employs the discourse of international competitiveness to impose collective responsibilities on teachers. In order to secure national prospects, performance management policy was introduced to distribute social returns to them according to their academic output, imprisoning them in the cage of performativity, and compelling them to win social recognition through productivity. This attempt is accomplished by enterprising subjects, constituted by teaching ethics through truth-telling embedded in exemplary demonstrations of excellent teachers. As teaching ethics is able to proliferate teachers' commitment to performance management, they are refabricated into governable subjects who look at their own and others' conduct, and this situation creates self-monitoring and collective surveillance, the combination of which molds a dominated context, in which governable teachers become conformists. While neoliberal governmentality is able to instill the vocabularies of responsibility and contribution to people's self-consciousness, teachers may not lose their subjectivities 
entirely, as evident in such actions as policy enactment, resistance and refusal. Teachers like this can be profiled as translators. Although the above theoretical correlations foreground the dark side of performativity, they may not precisely allocate different types of teachers into the matrix of actions because performance management may open up a huge space for productive teachers to exercise their academic advantages, the practice of which may come to develop the culture of neoprofessionalism. Based on these possible correlations, this study sets out to explore how productive university teachers may perceive, evaluate and react to performance management, and why.

\section{Research design}

According to the above associations, a logical model of the relation between performance management and neoprofessionalism emerges and details the interplay of all theoretical components of neoliberal governmentality, as shown in Fig. 1.

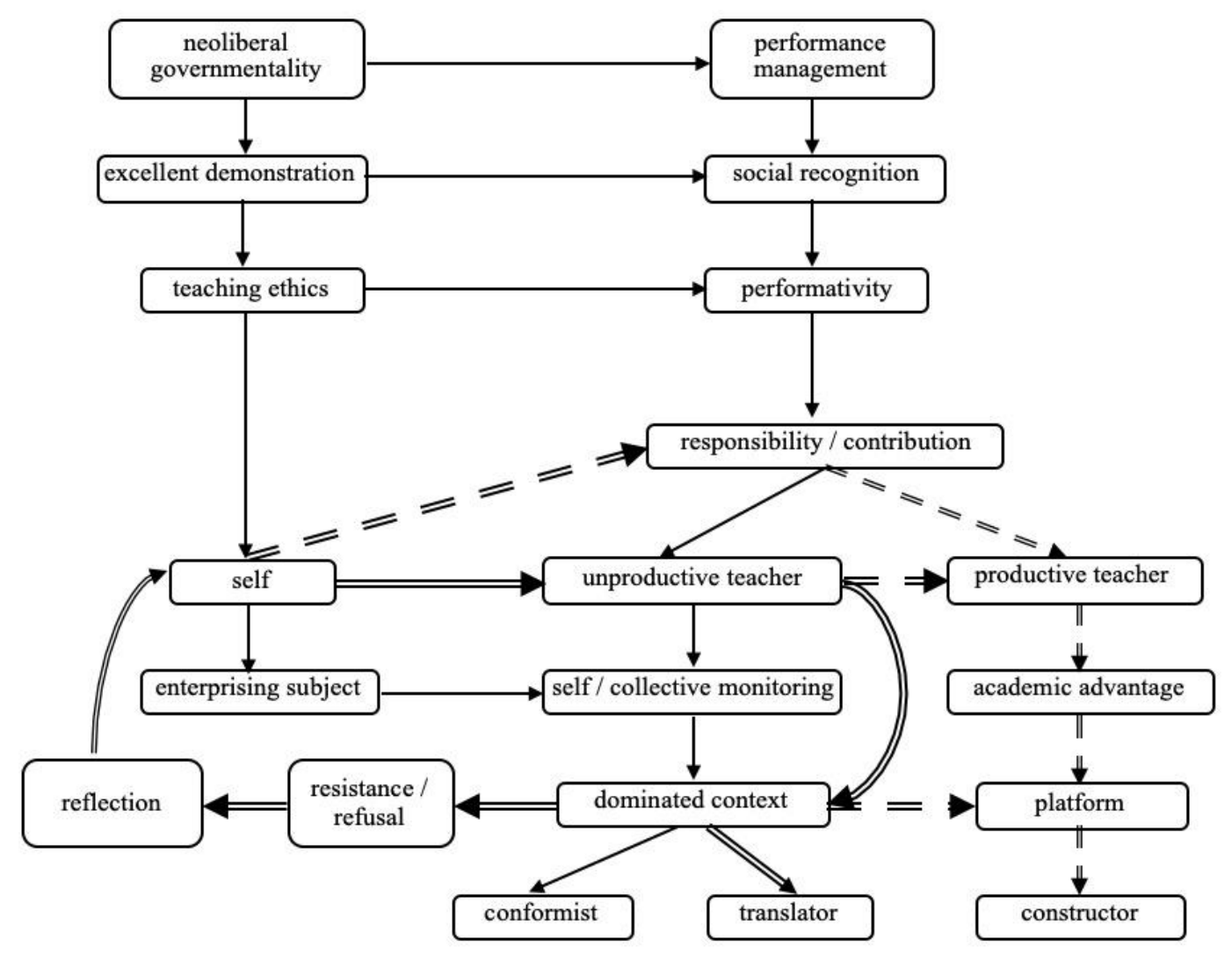

Fig. 1 A logical model of the relation between performance management and neoprofessionalism

In Fig. 1, the unbroken line represents the theoretical interactions illustrated at the end of literature review. The double broken line indicates how productive university teachers may perceive, evaluate and react to performance management, and why. As 
they have high aptitude for academic research, they may view the dominated context as a platform empowering them to exert their academic advantages. In this case, they would be expected to have different attitudes toward performance management from unproductive teachers. This relation casts an important research question: What are their perceptions of the dominated context formed by performativity? As performativity requires teachers to accomplish personal contributions and collective responsibilities, productive teachers may have a strong commitment to its requirements. This correlation prompts two interrelated research questions: What is their academic commitment? Does this commitment help them obtain social recognition through academic output? If it does, they may appreciate performance management. This situation suggests a further question: How do they interpret the relation between their academic output and organizational development? If this context assists them to exercise their academic advantages, two further questions emerge: How do they discover the rules of performance management? And what are their action strategies to perform such advantages?

Data collection was reliant upon semi-structured interviews examining the above research questions. The interviewees covered university administrators and faculty members in America, Greece, South Africa, Mainland China and Japan, the various geographical locations of which permitted us to uncover rather precise findings regulated by social cultures. After contact by email, four university administrators, who were either pro-vice chancellors, deans or department heads, and 12 faculty members agreed to participate in this study. They consisted of three American, three Japanese, two Greek, four South African and four Chinese. A total number of 16 individual interviews were completed from January 12, 2014 to July 20, 2014. All interviews were audio recorded and transcribed. Content analysis was adopted to analyze these texts in order to decode key words and concepts that were further categorized into the themes for presenting the findings. In terms of research ethics, all informants are anonymous in the findings.

\section{Findings}

The findings show that performance management created a dominated context imposing considerable pressure on university teachers. Although productive teachers complained about this milieu, they viewed this policy as a platform benefiting them by enabling them to secure personal gain through utilizing their academic advantages. Such utility was performed via the acknowledgeability uncovering the rules of the evaluation system by which joy and excellent status were attained. When social returns were encapsulated in performance management, such institutionalized rewards aided them to develop the culture of neoprofessionalism. 


\section{The dominated context created by performance management}

All informants reported that their institutes had implemented performance management policies with itemized indexes. This assessment, equipped with clear regulations, created a rigid milieu in which teachers were compelled to meet its requirements, so that the scope of their academic output was clearly predefined. Nevertheless, there were some variations between the sampled regions. The evaluation system in America tended to be flexible in order to meet the specialties of individual academics, as outlined by one informant:

Yes, my university has exerted a teacher appraisal policy. However, it consists of different aspects, covering administrative service, teaching obligations, public participation, academic performance and others. This design allows individual faculty members to decide the percentages of each aspect in their preferences... One of its principal purposes is to let a university teacher demonstrate his or her best ability in a certain field... For example, I am very good at teaching, so that I got a very high score in this evaluation. Some teachers are good at doing research, so they would focus on the aspect of publications. (John, Professor, America)

This flexibility also occurred in Japan and China. However, it resulted from the features of social cultures, addressing the harmonious relationship between people with the intention of reducing administrative conflicts generated by performance management. Therefore, the evaluation results didn't operate in a mandatory form but through personal contacts.

Yes, my university has introduced an evaluation system expecting faculty members to have more research grants and publications... However, it is not really mandatory and compulsory...This system doesn't apply to senior teachers. This is because Japanese society respects senior people or important persons. They normally have more influence on the operation of universities... My university won't take the evaluation results to punish teachers. We focus on positive aspects rather than negative spheres. For example, if a teacher could not pass this evaluation, the system allows him to submit a three year selfimprovement plan... If he/she fails again, the university just reminds him. (Aoki, Associate Professor, Japan)

Generally speaking, the evaluation results have some impact on teachers, 
including their promotions, salaries and rewards. However, teachers won't be fired when they fail in the evaluation... You know, personal relationships are a crucial issue in Chinese society. Furthermore, the face-oriented culture is a core character in Chinese society. If you criticize someone in public, he/she would feel humiliated and, in turn, he/she would initiate some radical reactions undermining the authority of university administrators... For university administrators, maintaining a harmonious atmosphere is very important... The university avoids this evaluation triggering conflicts between teachers and administrators. (ZhiPeng, Pro-Vice Chancellor, China)

While performance management placed new requirements on academics, it operated in different forms due to social cultures. The positions held by the interviewees further regulated their perceptions of and attitudes towards this policy. For most of the interviewees who were university administrators, the monitoring mechanism was necessary and positive because its mandatory authority aided university administrators to introduce regulations to upgrade their colleagues' academic commitment. This commitment was further activated by the competitive mechanism between university units, as described by a senior administrator:

My university has imported an evaluation system to all schools and departments. Its policy is to assess the performances of all academic units... Obviously, this system generates a competitive mechanism within this university, so that individual academic units not only need to comply with its imperative regulations but also to compete with each other... Certainly, some faculty members dislike this system and complain about it all the time. However, it is able to encourage them to have more publications and research projects... Well, there are always some teachers hiding in the dark. They do not have any contributions to organizational development. This evaluation system could make them productive in terms of research. (Peter, Dean, South Africa)

\section{Attitudes towards performance management}

Such competitive pressure not only occurred within universities but also extended to competition between higher education institutes in the sampled regions. China was a typical case for illustrating this phenomenon due to its strong compliance with neoliberalism:

Well, there are over two thousand higher education institutes in China and there are tremendous differences in quality between them. In this case, it is very 
important to identify and improve their quality in order to distribute education resources to them... Well, the national ranking system has some categories... The crucial issue is that this rank represents the academic reputation of individual institutes. If your institute cannot win a good reputation in this battle, it cannot recruit excellent students... It cannot obtain extra grants from the central government... Actually, local governments undertake a similar scheme as well... Academic output is the crucial element in improving your status in this ranking system (Wen-Hui, Dean, China)

While university superintendents were more concerned with academic reputation, university teachers displayed different attitudes towards this issue. Most faculty members interviewed had a lot of complaints about workload and pressure caused by performance management:

My colleagues who are not productive in terms of publications have a lot of complaints about the evaluation system. They contend that the core element in cultivating human capital is not mainly reliant on publications but teaching. For them, this system simply rejects their professional voice and judgments. (ChengLong, Pro-vice Chancellor, China)

The evaluation system expects faculty members to have more research grants and more publications. I am committed to doing research, so that the system doesn't affect me too much. However, this system always asks you to do more and more... This situation becomes very demanding... Furthermore, you need to fill out a lot of forms that are very trivial, time-consuming and meaningless... As far as I know, unproductive teachers have a lot of complaints about this system. For them, the evaluation system tends to make universities like factories that suffocate professional autonomy and voices. (Mary, Professor, South Africa)

Beside workload and pressure, some complaints were rooted in the practice of applying the same criteria for evaluation to all disciplines, as reported by a Greek teacher:

The criteria of the evaluation system are based on the thinking of natural sciences. You know, the character of the social sciences is very different from natural sciences. However, educational researchers are required to comply with the scientific rules... It is absurd. A scientific paper is normally very short, just about 3 or 4 pages. In contrast, an educational article is much longer than that... Can 
you produce so many journal articles annually like a scientist? It is not because you are lazy. It is because of different natures of disciplines... Besides, journal articles are now viewed as superior to book essays. Most distinguished educational scholars develop important theories not through journal articles but books. It is totally unfair again... Well, educational researchers are subject to the hegemonic status of natural sciences. (Nikos, Associate Professor, Greece)

As natural sciences have attained a hegemonic status in the world, this circumstance expected research output in the social sciences to emulate that of the natural sciences. In addition, the evaluation system tended to prioritize the status of English medium publications, particularly journals on the list of SSCI. For the interviewees of non-English speaking regions, this approach was unfair and unreasonable:

The criteria of the evaluation system appreciate English medium more, particularly the journals on the list of the SSCI. If your articles are published in such journals, you get a lot of credits on academic reputation... How can you expect those teachers who are not good at English to meet this criterion? (YongFeng, Professor, China)

\section{Joy, excellent status and agency}

Although performance management formed a repressive milieu in which teachers were subject to its instructions, it provided productive teachers with a platform to earn joy and social recognition, which functioned as a psychical incentive motivating them to utilize their academic advantages:

Well, you are demanded to have more research projects and publications. I am suffering from this situation. I really feel a lot of pressure... However, there is some joy when my articles are published in important journals or my research project applications are approved... It is not only a source of joy but also a feeling of achievement. (Charlie, Associate Professor, America)

I have travelled around the world to give lectures and do presentations at international conferences. You know it is not so easy to produce an article. You have to spend much time on reading, data collection and writing and others... Well, it is very hard to describe my job when I interact with the audiences after my presentation in a conference. (Despoina, Professor, Greece) 
Research projects are increasingly important in the evaluation system... This situation further leads to a change, in that the department culture is gradually coming to view research projects as the indicator of excellent researchers... It is the gateway for young faculty members like me to win honor and prestige... Well, research is time-consuming and I need to sacrifice my leisure time and I feel very stressed... However, I am pleased to be a productive researcher because I acquire a lot of achievement joy and social recognition. (Tracy, Professor, South Africa)

Academic performances not only amplified joy and the feelings of achievement but also discriminated whether a university teacher was excellent or not and, in turn, this differentiation crowned productive teachers with an excellent status in their institutes, which intensified their academic commitment.

Senior faculty members used to have a superior status in my department... The evaluation system changes this situation because it lets academic-oriented teachers exercise their talents... In other words, the reputation and status in my institute are no longer determined by age or other conditions but by academic achievements. (Laura, Associate Professor, South Africa)

Japanese culture respects senior people a lot. Although their viewpoints may not be reasonable, their voice is very authoritative... There is no point in challenging their authority... Academic performances let senior faculty members respect me... I know, they admire me a lot because I have been invited to give speeches in other countries. Well, it is not because of my age but my academic achievements. (Kano, Professor, Japan)

For productive teachers, performance management was no longer viewed as a structural constraint but a stage securing their personal advantages by exercising their academic talents. In this case, agency was exerted through structural rules.

Well, the evaluation system is very demanding and I really got the feeling of burn out... However, this design is not to exploit but provide you a new platform. This is because... your academic output will be scored and you get some advantages, such as reputation, promotion and money. (Peter, Dean, South Africa)

In the beginning, I was forced to conform to the evaluation system. However, after analyzing its contents I realized that academic output is its core component... 
Promotion is much like a queue according to seniority. Age is the priority on this agenda, so that senior teachers have more chance of getting promotions... You have to wait for a vacancy and for senior teachers to approve you... Although such a culture is still there, the evaluation system now provides new opportunities... If you are academically excellent, you would have more chances to get promotions. (Hashimoto, Professor, Japan)

You cannot interpret the evaluation system as a structural constraint that undermines university teachers' professional autonomy... Instead, it underpins the academic culture that facilitates a department to move forward... Besides, publications also affect teachers' personal advantages... A distinguished scholar is always honored and respected by his/her colleagues and the academic community... Excellent performances in research always have more advantages for claiming extra benefits such as promotion or income... If you do not want to follow this principle, you would become a nobody. (Nikos, Associate Professor, Greece)

\section{Institutionalized rewards and neoprofessionalism}

Whereas academic performances spurred an academic inclination, this motivation was largely retained in the psychical world of individual teachers. Material rewards, such as promotion and remuneration, not only objectified their personal intentions but also fused them into a collective form leading to the development of neoprofessionalism. In this regard, performance management created an institutionalized form, by which productive teachers were able to utilize their academic advantages to gain social returns. One American interviewee said that albeit the remuneration offered to academically excellent teachers was rather limited, it embodied the symbolic capital that certified the official recognition of someone who manifested excellent performance in research:

If you are good enough, you can negotiate your salary with the director or the dean... Its range is about 5 percent... Although other universities may offer you better conditions, such as housing rental allowances, good salaries and others, people are very rational, so that they will calculate the total costs of a new situation... As far as I know, very few colleagues of mine transferred to other universities... Well, if you are really outstanding in a specific field, the dean will do something not letting you leave. However, the dean can only increase your salary up to about 7 or 8 percent... Although the remuneration is not too much, you are officially recognized as excellent or distinguished scholars by the 
university. This recognition is really something and it is a great honor that many people pursue. (Paul, Emeritus Professor, America)

Although such symbolic capital was meaningful in China as well, the Chinese government introduced the mechanism of competition into the higher education market and this action encouraged university administrators to use material rewards as the incentive to augment teachers' commitment to increasing their academic output. In this case, academic excellence not only aided productive teachers to achieve high status within a university but also served as credits for claiming substantial rewards nationally. Therefore, discovering such correlations facilitated them to secure personal gains:

Most higher education institutes take research projects approved by either the National Natural Science Foundation of China or the National Social Science Foundation of China as the key meter of the teacher evaluation policy due to the national policy... If you are awarded such research projects, you will be recognized as an important researcher. It becomes a gateway to establishing your academic reputation... Such projects also give you a lot of credits enabling you to claim yourself as a well-known scholar. The national policy allows higher education institutes to compete with each other... Many universities want to recruit important scholars at very good salaries that would be even over 10 times the amount of regular salaries... Some local authorities in economicallyadvanced areas provide their local universities with strong financial support for employing well-known scholars in order to enhance their national reputations. (Yong-Feng, Professor, China)

\section{Discussion}

The above findings show that performance management constituted an oppressive context, in which academics were required to fulfil their responsibility through their academic output, which affected the academic reputation of their institutes. While this obligational implementation was correspondent with other studies (Ball, 1998; Robertson, 2012), our study further uncovered that performance management policy was accomplished in varied ways in the sampled regions due to the influence of their social cultures, as evident in the flexibility in America optimizing teachers' specialties and the concern for harmonious relations in China and Japan and the avoidance of administrative conflicts. These variations were partly attributed to positions held by the participants, as witnessed by the fact that university administrators viewed the competition promoted by this policy as an instrument for enlarging their colleagues' academic yields. This administrative culture was consonant with the findings of 
Morrissey (2013).

Although faculty members disliked this policy because of a variety of issues, such as increased workload, pressure, use of the same criteria for evaluation without reference to the special character of education, and the hegemonic status of English medium publications, productive teachers interpreted this repressive context as a platform benefiting them to acquire joy, social recognition and status through the utilization of their academic advantages, the acquirement of which intensified their academic commitment. Such psychical perceptions came to confirm the features of performativity (Ball, 2003, 2006; Ball and Olmedo, 2013). However, these teachers did not play the function of translators (Maguire, Braun and Ball, 2015) or resistant actors (Ball and Olmedo, 2013; Maguire, Braun and Ball, 2018). Instead, they behaved as symbolic capital constructors who were able to amplify their academic talents and to secure their personal gains through the exercise of agency acquired by the discovery of the rules of performance management policy. Because social returns were encapsulated within this policy, institutionalized rewards not only functioned as an interface objectifying their personal intentions but also served as a conduit for integrating individualized preferences into a collective channel, espousing the growth of neoprofessionalism. In some ways, productive teachers may act as responsible or enterprising subjects created by devolution (Ball, 1998; Codd, Gordon and Harker, 1997) or by the combination of technologies of agency and technologies of performance (Dean, 2010) because they have devoted themselves to pursuing promotion, remuneration, dignity, honor and pride. Furthermore, their exemplary demonstrations may disseminate teaching ethics, so that this teacher group performed as truth-tellers (Perryman, Ball, Braun and Maguire, 2017). At any rate, their dedication was activated by the interplay between outside force and inner drive. Even though this devotion may be provoked by belief (Ball, 2003), engagement (Ball, 2016) or care of self (Perryman, Ball, Braun and Maguire, 2017), productive teachers were not really forced by performance management but actively participated in its operation. Because performance management accommodated their academic commitment, active participation was stimulated. Such an accommodation and constructive participation converted self-monitoring and collective surveillance into an array protecting the teachers' academic commitment. This protection aligned self-reflection with collective responsibility and organizational contribution. However, such an alignment led to mental reinforcement because it came to validate the utilities of self-knowledge. This situation deviated from the linkage between reflection and subjective reinstallation, argued by Ball (2016) and Ball and Olmedo (2013). In this regard, performance management provided a legitimate space for productive teachers to attain the practice of academic talent, commitment, devotion and self-validation, which subscribed the 
development of neoprofessionalism, reducing the culture of anti-intellectualism in higher education institutes. This unanticipated consequence thus denotes the doctrine that in the regime of neoliberal governmentality, productive teachers may perform as catalysts.

\section{Conclusions}

Governmentality articulates a governing creed that the self is the nexus between self-regulation and social control. Self is about subjectivity, directing behaviour, so that in order to create governable subjects, ethics, relayed through truth-telling, is employed to format self-knowledge via souls. Neoliberal governmentality adopts these governing technologies to transform teachers into responsible subjects. Governing techniques, such as devolution and competition, come to refabricate them into enterprising subjects committed to competing for social recognition through their achievements. Such performativity is further reinforced by the discourse of international competitiveness, constituting a linear relation between education, human capital and national economic development, which requires teachers to contribute to national economic development. Performance management is viewed as an effective tool for securing this national mission. Although academics are required to comply with the requirements of performance management, there is a gap between self and neoliberal governmentality, as evident in the phenomenon of enactment, resistance or refusal in the processes of policy performance.

While our research confirmed the influence of performativity on academics, its findings further show that productive faculty members did not define performance management policy as an exploitive device but a platform enabling them to win academic status, promotion and remuneration, and to accomplish their responsibility to organizational development. In this regard, they can be conceptualized as symbolic capital constructors, as evident in their active participation in performance management policy, which was activated by the consistency between its requirements and their academic talents, by which they validated their academic commitment. Such validation not only safeguarded their personal gains but also energized a collective culture promoting the status of academic research. This academic-led culture thus underpinned the development of neoprofessionalism and reduced anti-intellectualism.

As productive teachers perform as truth-tellers via their excellent academic attainment, neoliberal governmentality needs to increase social returns distributed by performance management, which can validate the academic commitment of such teachers. This validation is not social alchemy deceiving people's minds but social therapeutics, enhancing their ambitions because social therapeutics promises able people great opportunities to actualize their beliefs and acquire rewards. Whereas social 
therapeutics aims at targeted souls, its strategy is not to force people but to encourage them. This social engineering can be accomplished by models, incarnated by productive teachers, whose modes of operation can be emulated. As neoliberal governmentality is devoted to converting teachers into enterprising subjects who generate automatic actions, the interaction between examples and emulations serves as a recipe for exercising social therapeutics. In this sense, neoprofessionalism functions as catalyst that is able to strengthen the academic commitment of the targeted population to contributing to organizational development. The task of spiritual therapy thus becomes workable because when neoprofessionalism inscribes in teachers' souls an active subscription to the linkage between achievement and social return, performance management implements a new form of governing technology, leading people to become contributors to society. On the one hand, it endorses the academic impulses of productive teachers through social rewards, identifying them as role models for others. Their academic validation is no longer retained within the personal sphere of asceticism, care of self or agonist but the collective aspect of ethical examples. On the other hand, performance management invisibly performs the mechanism of social sanction, devaluing anti-intellectualism attributed to those teachers behind society. The combination of introspective inclination and extrospective incentive functions as pastoral guidance, like a book constantly reminding all teachers to become selfimprovers. Thus, social therapeutics can be described as the practice of spiritual therapy accomplished through neoprofessionalism, or neoliberal professionalism, which is the core assignment of neoliberal governmentality.

\section{References:}

Andersson, P. and Fejes, A. (2005). Recognition of prior learning as a technique for fabricating the adult learner: A genealogical analysis on Swedish adult education policy. Journal of Education Policy, 20(5): 595-614.

Ball, S. (1998). Big policies/small world: An introduction to international perspectives in education policy. Comparative Education, 34(2): 119-130.

Ball, S. (2003). The teacher's soul and the terrors of performativity. Journal of Education Policy, 18(2): 215-228.

Ball (2006). Performativities and fabrications in the education economy: Towards the performative society. In H. Lauder, P. Brown, J. Dillabough and A.H. Halsey (eds.), Education, globalization \& social change (pp. 692-701). Oxford: Oxford University Press.

Ball, S. (2016). Subjectivity as a site of struggle: Refusing neoliberalism? British Journal of Sociology of Education, 37(8):1129-1146

Ball, S. and Olmedo, A. (2013). Care of self, resistance and subjectivity under 
neoliberal governmentalities. Critical Studies in Education, 54(1): 85-96.

Blackmore, J. (2006). Localization / globalization and the midwife state: Strategic dilemmas for state feminism in education. In H. Lauder, P. Brown, J. Dillabough and A. Halsey (eds.), Education, globalization \& social change (pp. 212-227). Oxford: Oxford University Press.

Bok, D. (2003). Universities in the marketplace: The commercialization of higher education. Princeton: Princeton University Press.

Chiang T.H. (2011). How globalization drives the higher education policy of the State. Journal of Education Sciences, 1, 7-20.

Chiang, T.H. (2014). Globalization, market logic, the state and the resettlement of higher education. Issues of History of Education, 12, 3-24.

Chiang, T.H. (2016). Public managerialism functions as a discourse to regulate higher education in the era of globalization. Czech-Polish-Slovak Studies in Andragogy and Social Gerontology, Vol. V, 163-178.

Chiang, Tien-Hui (2020). Steering at a distance: The issue of lifelong learning at the age of neoliberal governance. Academia, 18, 41-57.

Codd, J. Gordon, L. and Harker, R. (1997). Education and the role of the state: Devolution and control post picot. In A.H. Halsey, H. Lauder, P. Brown and A.S. Wells (eds.), Education, culture, economy and society (pp. 263-272). Oxford: Oxford University Press.

Currie, J. (2004). The neo-liberal paradigm and higher education: A critique. In J.K. Odin and P.T. Manicas (eds.), Globalization and higher education (pp. 42-62). Hawai: University of Hawaii's Press.

Dean, M. (2010). Governmentality: Power and rule in modern society $\left(2^{\text {nd }}\right)$. London: Sage.

Foucault, M. (1990). The history of sexuality. London: Penguin.

Foucault, M. (1991). Discipline and punish: The birth of the prison. London: Penguin.

Foucault, M. (2003). Society must be defended. New York, N.Y.: Picador.

Foucault, M. (2005). The hermeneutics of the subject. New York, N.Y.: Picador.

Foucault, M. (2010). The birth of biopolitics. New York, N.Y.: Palgrave Macmillan.

Foucault, M. (2011). The government of self and others. New York, N.Y.: Palgrave Macmillan.

Gewirtz, S. (2008). Give us a break! A skeptical review of contemporary discourse of lifelong learning. European Educational Research Journal, 7(4): 414-424.

Harvey, D. (2005). A brief history of neoliberalism. Oxford: Oxford University Press.

Heywood, A. (2003). Political ideologies ( $3^{\text {rd }}$ edition). Basingstoke: Palgrave Macmillan. 
Hytrek, G. and Zentgraf, K.M. (2008). America transformed: Globalization, inequality, and power. New York, N.Y.: Oxford University Press.

Lingard, B. (2000). It is and it isn't: Vernacular globalization, educational policy, and restructuring. In N.C. Burbules and C.A. Torres (eds.), Globalization and education: Critical perspectives (pp. 79-108). New York, N.Y.: Routledge.

Maguire, M, Braun, A. and Ball, S. (2015). 'Where you stand depends on where you sit': The social construction of policy enactments in the (English) second school. Discourse, 36(4), 485-499.

Maguire, M, Braun, A. and Ball, S. (2018). Discomforts, opposition and resistance in schools: The perspectives of union representatives. British Journal of Sociology of Education, 39(7), 1060-1073.

Morrissey, J. (2013). Governing the academic subject: Foucault, governmentality and the performing university. Oxford Review of Education, 39(6): 797-810.

Olmedo, A., Bailey, P.L. and Ball, S. (2013). To infinity and beyond... heterarchical governance, the teacher for all network in Europe and the making of profits and minds. European Educational Research Journal, 12(4): 492-512.

Perryman, J., Ball, S., Braun, A. and Maguire, M. (2017). Translating policy: Governmentality and the reflective teacher. Journal of Education Policy, 32(6): 745-756.

Popkewitz, T.S. (1994). Professionalization in teaching and teacher education: Some notes on its history, ideology, and potential. Teaching \& Teacher Education, 10, $1-14$.

Rizvi, F. and Lingard, B. (2006). Globalization and the changing nature in the OECD's educational work. In H. Lauder, P. Brown, A. Dillabough and A.H. Halsey (eds.). Education, globalization and social change (pp.247-260). Oxford: Oxford University Press.

Robertson, S. (2012). Placing teachers in global governance agendas. Comparative Education Review 56(4), 584-607.

Robertson, S. Bonal, X. and Dale, R. (2006). GATS and the education service Industry: The politics of scale and global reterritorialization. In H. Lauder, P. Brown, J. Dillabough and A. Halsey (eds.). Education, globalization and social change (pp. 228-246). Oxford: Oxford University Press.

Rose, N. (1999). Governing the soul. London: Free Association.

Säfström, C.A. (2005). The European knowledge society and the diminishing state control of education: the case of Sweden. Journal of Education Policy, 20(5): 583-593.

Singh, P. (2015). Performativity and pedagogising knowledge: Globalising education policy formation, dissemination and enactment. Journal of Education Policy, 
30(3):363-384.

Singh, P., Heimans, S. and Glasswell, K. (2014). Policy enactment, context and performativity: Ontological politics and researching Australian National Partnership policies. Journal of Education Policy, 29(6), 826-844.

Singh, P., Pini, B. and Glasswell, K. (2018). Explorations in policy enactment: Feminist thought experiments with Basil Bernstein's code theory. Gender and Education, 30(4), 417-434.

Singh, P., Thomas, S. and Harris, J. (2013). Recontextualising policy discourses: A Bernsteinian perspective on policy interpretation, translation and enactment. Journal of Education Policy, 28(4), 465-480.

Stiglitz, J. (2006). Broken Promises. In J. Krieger (ed.), Globalization and state power (pp. 36-48). New York, N.Y.: Pearson.

Thompson, G. and Cook, I. (2014) Education policy-making and time, Journal of Education Policy, 29(5), 700-715. 